Cahiers $d u$ MONDE RUSSE

\section{Cahiers du monde russe}

Russie - Empire russe - Union soviétique et États indépendants

$60 / 4 \mid 2019$

Varia

\title{
Randall A. POOLE, Paul W. WERTH, eds., Religious Freedom in Modern Russia
}

\author{
Emily B. Baran
}

\section{OpenEdition}

\section{Journals}

Electronic version

URL: https://journals.openedition.org/monderusse/11557

DOI: 10.4000/monderusse. 11557

ISSN: $1777-5388$

\section{Publisher}

Éditions de l'EHESS

\section{Printed version}

Date of publication: 1 October 2019

Number of pages: $871-874$

ISBN: 978-2-7132-2797-4

ISSN: $1252-6576$

Electronic reference

Emily B. Baran, "Randall A. POOLE, Paul W. WERTH, eds., Religious Freedom in Modern Russia", Cahiers du monde russe [Online], 60/4 | 2019, Online since 01 October 2019, connection on 10 January 2023. URL: http://journals.openedition.org/monderusse/11557 ; DOI: https://doi.org/10.4000/ monderusse. 11557 
Randall A. POOLE, Paul W. WERTH, eds.

\section{Religious Freedom in Modern Russia}

Pittsburgh : University of Pittsburgh Press, 2018, 312 p.

This edited volume fits in with a sustained surge in scholarship on lived religious experience in modern Russia. As such, the authors in this volume focus the bulk of their attention on non-state actors, even as they acknowledge the fact that the imperial Russian state loomed large over religious communities and had a profound impact on them. Given this fact, it is not surprising that co-editor Paul W. Werth's seminal definition of the Russian Empire as a "multiconfessional Orthodox statethat is a polity that established several religions while constituting only one of them as dominant," is a critical framework for many of the authors (9).

Randall A. Poole's introduction offers an extensive overview of evolving notions of freedom of conscience in modern Russia. The volume directs most of its attention to intellectual and philosophical developments within Russian Orthodoxy, a limitation he acknowledges at the outset. This focus is understandable given Orthodoxy's outsized role in the multiconfessional empire. That said, the contributions by Coleman and Naganawa do much to broaden this focus beyond Orthodoxy. Poole also draws a necessary distinction between religious toleration and religious freedom, as the two terms have divergent meanings in the imperial period. He characterizes the nineteenth and early twentieth century as a period of sustained 
religious revival, a development that was interwoven with growing awareness of and articulated demands by religious subjects of the empire for individual freedom and human dignity.

While Poole stresses religious freedom in his introduction, G.M. Hamburg tackles the separate question of religious toleration in a chapter that provides an intellectual prehistory to the other chapters. Hamburg explores the intellectual evolution of the term "religious toleration" in the Russian context from 1500 to 1825 . As have other historians, Hamburg critiques the notion that toleration emerged primarily from the Enlightenment, noting that Russian thinkers considered toleration well before this period, and that only with Catherine's reign did the Enlightenment significantly impact Russian writing on the subject. Even after this point, those who endorsed toleration did so within prescribed limits and for its assumed practical advantages.

The remaining chapters largely focus on nineteenth century developments. Patrick Lally Michelson addresses the intellectual trajectory of Orthodox clerical thought on freedom of conscience in the first half of the century. His chapter carefully scrutinizes the writings of Archimandrite Ioann, whose understanding of freedom of conscience was essentially freedom from sin and the resultant ability of an Orthodox believer to commune with God with a clear conscience. Michelson concludes that Archimandrite Ioann offered a novel critique of both liberal definitions of the term and Russian state intervention in church governance.

For her part, Victoria Frede describes how the conspiratorial revolutionary organization, Land and Freedom, grappled with the thorny issue of freedom of conscience in the 1860s. While such early revolutionaries saw in sectarians and Old Believers a critical base of support for their radical goals and made freedom of confession a component of their public appeals, it became apparent over time that dissenting believers did not share with political radicals the same commitment to universal freedom of conscience. By and large, they wanted the freedom to practice their faith, but did not necessarily want this freedom extended to others whose beliefs they did not share.

Norihiro Naganawa identifies a similar understanding of freedom of conscience among Muslim Tatars. His chapter is one of two contributions that address the issue of religious freedom from outside of the Russian Orthodox perspective. In the wake of the 1905 Revolution, Muslim Tatars in the Volga-Urals region used the term "freedom of religion" (hurrîyat-i dînîya) primarily as a vehicle to demand greater collective rights for their own community. Naganawa focuses on the Orenburg Mohammedan Spiritual Assembly, an important body for interaction between the Russian state and its Muslim population, in order to highlight the development of a Muslim public sphere after 1905. He situates the emergence of a public sphere in the circulation of the printed word, namely booklets and newspapers, that allowed for a rich public dialogue over the need for reform and its proper parameters. The lack of consensus in the press on the reform question gave the Muslim community access to a diversity of viewpoints, even if the term "freedom of religion" remained centered on collective rights for Muslims, rather than individual rights to choose one's faith, including outside of the Muslim tradition. 
Like Frede, Heather J. Coleman examines the extent to which religious minorities were imagined as supporters of a new order in Russia, one in which freedom of conscience would be realized. In her contribution, she explores public advocacy by British liberals and evangelical Protestants on behalf of "stundists" in the final decades before the revolution. Unlike Frede, Coleman does not delve into the question of how well this imagined stundism fit with the real lived experiences and goals of actual stundists in the Russian Empire. The catch-all nature of the term "stundists," which was broadly used to refer to Russian evangelicals, proved useful in making the Russian religious landscape more accessible to outsiders and in drawing commonalities between communities of evangelicals across the western world. Harrowing tales of persecution and martyrdom by stundists allowed British evangelicals to center the fight for religious freedom within their own religious tradition, to unite across denominational lines, and to rally the faithful to see religious freedom as an unfinished task both at home and abroad. Moreover, the sheer presence of Russian evangelicals suggested to British advocates that Russia could embrace a more liberal, western political future, and that religion was key to this possibility.

Daniel Scarborough offers a compelling reassessment of earlier scholarly conclusions about late nineteenth century religious intolerance, which tended to see Orthodox Christianity writ large as largely to blame for this situation. In contrast, Scarborough links the relative failure of religious toleration in this period instead to a small minority within the Orthodox Church, namely official missionaries, who emerged as a result of the growth in free associations following the Great Reforms. These associations hindered interfaith dialogue and the development of a pluralistic religious environment even after the 1905 revolution. Overall, Scarborough argues that the Orthodox Church's privileged status in the Russian Empire actually undermined its ability to adapt to the emergent civil society and remain relevant to the local population. He closes by drawing a comparison to the current post-Soviet favoritism of Orthodoxy, as enshrined in the 1997 religious law, suggesting that such continued state sponsorship of Orthodoxy will only "weaken its influence" among the population rather than strengthen it (159).

J. Eugene Clay's contribution to the volume focuses entirely on this particular law, and in that sense is an outlier from the other chapters both in its comparative approach and focus on contemporary history. Clay examines the state of religious freedom after the passage of the controversial 1997 law on freedom of conscience. He contends that despite widespread fears that the law would fundamentally undercut religious freedom in Russia, minority religious communities proved remarkably adaptable to the new regulations. The four case studies he presents show minority communities carefully reframing themselves as "traditional faiths" in order to successfully navigate the new regulatory reality.

As a whole, this volume offers a welcome addition to the growing scholarship on religious freedom in Russia. While much of this scholarly activity has understandably focused on the post-Soviet period, the authors in this volume offer a longer history, one embedded both in Orthodoxy and other faiths, and with a rich 
intellectual tradition in the Russian Empire. Future scholars may want to continue this work by drawing deeper connections between the late imperial and post-Soviet periods, as suggested by Scarborough's and Clay's contributions in particular. Likewise, the editors might have included a conclusion to do more to highlight some of the overarching themes across the individual chapters. This is a minor criticism, however, in what is a successful and well researched contribution to the field of Russian late imperial and religious history.

Emily B. Baran

Department of History, Middle Tennessee State University 